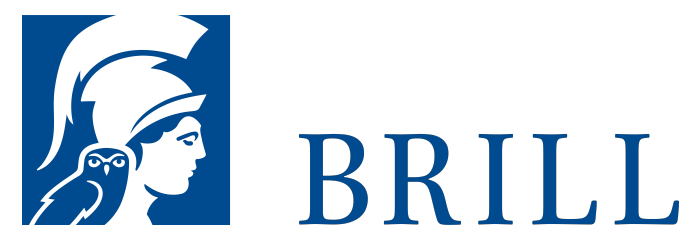

\title{
Friedrich Gentz
}

Die Erfindung der Realpolitik

Author: Harro Zimmermann

Harro Zimmermann begibt sich auf die Spur einer schillernden Persönlichkeit des 19. Jahrhunderts. Er stellt Gentz in allen seinen Facetten vor: den staatsphilosophischen Theoretiker des moderaten Konservatismus, den antifranzösischen Publizisten, den Glücksspieler und Verführer von Theaterschönheiten, den altersmild gewordenen Sekretär Metternichs. Die lange überfällige neue Biographie einer zentralen Gestalt im Zeitalter des Wiener Kongresses!

Mit großer Sachkunde lässt der Autor die Epoche der Französischen Revolution und des Wiener Kongresses lebendig werden, wenn er seinen Helden an dessen Wirkungsstätten begleitet, die heißen Debatten für und wider Revolution und Napoleon erneut aufleben lässt oder nachspürt, mit wessen Hilfe Gentz seine immensen Spielschulden in letzter Minute begleichen konnte.

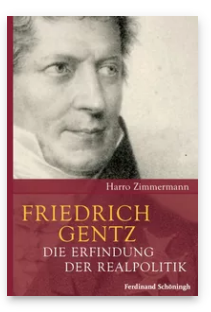

Pages: 344

Seiten

Language:

German

Subjects:

General, History

Publisher: Brill |

Schöningh

E-Book (PDF)

Released online:

O3 Jan 2013

ISBN: $978-3^{-}$

657-77132-5

List price

USD $\$ 63.00$

Hardback

Publication date:

13 Aug 2012

ISBN: 978-3-

506-77132-2

List price

USDD \$63.00 
Harro Zimmermann, Prof. Dr., geb. 1949, seit 1988 Kulturredakteur bei Radio Bremen; Professor für Neuere Deutsche Literaturwissenschaft an der Universität Bremen. Autor zahlreicher Publikationen zur Literatur-, Kultur- und Mentalitätsgeschichte des 18. bis 21. Jahrhunderts.

For more information see brill.com

\author{
Order information: Order online at brill.com \\ +44330 3330049 | customerservices@brill.com \\ Submission information: brill.com/authors
}

Titles published by Brill | Fink, Brill | mentis or Brill | Schöningh: +49(o)71 5413279216 | brill@brocom.de 